\title{
Study of occupation and amyotrophic lateral sclerosis in a Danish cohort
}

\author{
Aisha S Dickerson, ${ }^{1,2}$ Johnni Hansen, ${ }^{3}$ Marianthi-Anna Kioumourtzoglou, ${ }_{1}^{4}$ \\ Aaron I Specht, ${ }^{2}$ Ole Gredal, ${ }^{3}$ Marc G Weisskopf ${ }^{1,2}$
}

- Additional material is published online only. To view please visit the journal online (http://dx.doi.org/10.1136/ oemed-2018-105110).

${ }^{1}$ Department of Epidemiology, Harvard T.H. Chan School of Public Health, Boston, Massachusetts, USA ${ }^{2}$ Department of Environmental Health, Harvard T.H. Chan School of Public Health, Boston, Massachusetts, USA ${ }^{3}$ Danish Cancer Society, Institute of Cancer Epidemiology, Copenhagen, Denmark ${ }^{4}$ Department of Environmental Health Sciences, Columbia University Mailman School of Public Health, New York, USA

Correspondence to Dr Aisha S Dickerson, Department of Epidemiology, Harvard T.H. Chan School of Public Health, Boston, MA 02115, USA;

adickerson@hsph.harvard.edu

Received 5 March 2018 Revised 24 May 2018 Accepted 28 May 2018 Published Online First 25 June 2018

\section{ABSTRACT}

Objectives Several manuscripts have proposed associations between amyotrophic lateral sclerosis (ALS) and occupational toxicant exposures - not to mention physical activity and trauma/injury. Some have also reported associations in investigations of specific occupations. Using data from a prospective Danish cohort study, we investigated the association between employment in certain industries and ALS diagnosis. Methods We identified 1826 ALS cases who were 25 years old or less in 1964 and diagnosed from 1982 to 2013 from the Danish National Patient Registry then matched 100 population controls to each case based on birth year and sex. Demographic data were linked to the Danish Pension Fund to determine occupation history. Conditional logistic regression models were adjusted for socioeconomic status, marital status and residential location at the index date.

Results There was an increase in odds of ALS among men who worked in agriculture, hunting, forestry or fishing (adjusted OR $(\mathrm{aOR})=1.21 ; 95 \% \mathrm{Cl} 1.02$ to 1.45). There was also a positive association for men employed in construction $(\mathrm{aOR}=1.21 ; 95 \% \mathrm{Cl} 1.05$ to 1.39). In women, a protective association was seen with employment in the cleaning industry $(\mathrm{aOR}=0.69 ; 95 \% \mathrm{Cl}$ 0.52 to 0.93 ).

Conclusions Our study shows various occupations with exposure to toxicants, such as diesel exhaust and lead, and strenuous physical activity associated with increased odds of ALS in men. Future studies should have a particular focus on gathering detailed information on physical exertion and toxicant exposures specific to certain job tasks.

\section{INTRODUCTION}

Amyotrophic lateral sclerosis (ALS) is a rare and complex neurodegenerative condition with characteristically rapid progression of weakness and loss of voluntary motor function. ${ }^{1}$ Incidence is generally higher in men and whites, and increases with age. ${ }^{1}$ Although it is known that 5\%-10\% of ALS cases are hereditary, the causes for sporadic of ALS are generally unknown. ${ }^{2}$ The aetiology of ALS is believed to be multifactorial, but overall not well understood. ${ }^{2}$ Evidence suggests that manifestation and progression of ALS may be the result of genetic and environmental factors, or an interaction between both. ${ }^{1}$

Several manuscripts have proposed associations between ALS and occupational exposures, ${ }^{3}$ including electromagnetic fields, ${ }^{4}$ lead ${ }^{5}$ diesel exhaust, ${ }^{6}$ solvents ${ }^{5}$ and agricultural pesticides, ${ }^{5} 7$
Key messages

What is already known about this subject?

- Previous studies have proposed associations between amyotrophic lateral sclerosis (ALS) and occupational exposures with conflicting results.

- Prior studies of occupation and ALS have used retrospectively collected occupation history in small study samples, only one occupation held the longest, occupations at a certain time point or reported occupations from death certificates.

\section{What are the new findings?}

- Using prospectively collected surveillance data, we observed a positive association between occupations in agriculture, hunting, forestry, or fishing and construction among men.

- Associations seen in construction workers increased with increasing time between exposure windows and diagnosis dates.

How might this impact on policy or clinical practice in the foreseeable future?

- Considering that the occupations found to be positively associated have common exposures, including lead, diesel exhaust and injury, further research should reveal which of these exposures, separate or combined, has the greatest impact on risk of ALS.

- If replicated in future studies, these findings would suggest that early life environmental and physical injury could contribute to neurodegeneration later in life.

as well as physical activity and injury. ${ }^{8} 9$ Previous studies have also reported increased risk of ALS in subjects employed in specific occupations, such as truck and bus drivers, ${ }^{6}$ and agricultural workers. ${ }^{7}$ Yet results for associations with specific occupations have been conflicting.

Many of the prior studies of occupation and ALS have used retrospectively collected occupation history in small study samples, only one occupation held the longest, occupations at a certain time point or reported occupations from death certificates. In this study, we have attempted to overcome these limitations by using data from the National Danish Patient Registry and prospectively collected occupation data to conduct a nested case-control study of occupation and ALS diagnosis between 1982 and 2013. 


\section{MATERIALS AND METHODS}

\section{Case ascertainment}

The Danish National Patient Registry provides information on primary discharge diagnoses for all hospital admissions in Denmark since 1 January $1977 .{ }^{10}$ We determined ALS case status using the International Classification of Diseases and Related Health Problems, Eighth Revision (ICD-8) code of 348.0 (ALS) for records through 1994 and the Tenth Revision (ICD-10) code of G12.2 (motor neuron disease) thereafter. Validation of this process has been described previously. ${ }^{11}$ To prevent inclusion of prevalent cases in this study, case definition was limited to first recorded diagnoses beginning on 1 January 1982, 5 years after potential inclusion in the registry. The first recorded hospitalisation with an ALS indication was designated as the index date for study participants, with case ascertainment conducted through 31 December 2013.

\section{Control selection}

The Central Person Registry, established in 1968, contains basic demographic information for all residents in Denmark. ${ }^{12}$ We used this data source to randomly select and match 100 controls to each ALS case based on age (within 1 year), sex and vital status at the diagnosis date of the matched case (index date). We then used unique resident identifiers to link demographic data to that of the Danish National Patient Registry and the nationwide Danish Pension Fund.

\section{Occupation history}

Since 1 April 1964, the Danish Pension Fund has maintained data for the employment history of all Danish residents 16-66 years of age. ${ }^{13}$ In this database, the start and end dates of each job held are listed and can be linked to the previously mentioned unique indentification (ID) numbers of all ALS cases and controls in the study. Additionally, each employment record is assigned an employer tax ID number. Each company is also classified by a five digit extended version of the International Standard Industrial Classification codes. All companies in Denmark are classified into main branches, with up to three sub-branches based on the company's most important economic activity. Sub-branches also have an additional 579 subclassifications with more detailed information on company employee activities, which are presented in the online supplementary material. For the purposes of this study, we used 38 primary occupational classifications, based on the two digit United Nations Issued International Standard Industrial Classification of all Economic Activities and adapted for Danish occupations. ${ }^{14} 15$ Additional subclassifications for agriculture, hunting, forestry and fishing; food, beverage and tobacco packaging; chemical production industry, metal products industry, construction and building, trade, and transportation, were included based on size of subcategories, risk of environmental exposures (eg, diesel exhaust, heavy metals and chemical solvents) and significance of results in larger categories.

We also excluded study subjects who were more than 25 years old on the 1 April 1964 start date of the Danish Pension Fund (born in 1939) to further reduce exposure misclassification for those with occupations held prior to the start of the available employment history. ${ }^{16}$ Regarding military occupations, since 1973 men meeting minimum health standards have been required to register for up to 1 year of military service in Denmark. Thus, our classification of ever serving in the military was limited to those who served for at least 1 year.
For each occupation category, we calculated the total number of cases and controls ever employed at least 3 years before their reported index dates, while those never employed in that category or only employed in it within 3 years of their index date were classified as unexposed for that specific job category. For occupations with statistically significant differences in risk of ALS in sex-stratified analyses, we investigated associations between timing and length of employment. We categorised years of employment as none, $<1$ year, $1-4$ years and $\geq 5$ years. Age at first employment included the following categories: none, $\leq 20$ years, $21-30$ years, $31-40$ years and $\geq 41$ years. Because employment reporting began in 1964, we categorised the first year of employment as $\leq 1964$, 1965-1974, 1975-1984 and $\geq 1985$. For these analyses of length and timing of employment, we used multivariable logistic regression analyses with adjustment for the previously mentioned potential confounders (socioeconomic status (SES), residential location and marital status). All analyses were completed using SAS V.9.4. ${ }^{17}$

\section{Statistical analysis}

Because many women in our study population had never entered the workforce and we expected type of occupations to differ for men versus women, we stratified our analyses by sex. We used conditional logistic regression analyses to estimate ORs and 95\% CIs for each occupation category. In our tables we do not report occupations with less than five total ALS cases.

\section{Covariates}

In addition to the matching variables of age, sex and vital status, we used multivariable models to also adjust for SES, area of residence and marital status. The five category definition of SES used in this study is based on specific job titles from income tax forms at the time of the index date. Group 1 consists of academics and corporate managers; group 2 is composed of personnel with high salary positions, such as business owners, managers of small businesses and teachers; group 3 included low salary positions, such as nurses and technicians; group 4 was representative of skilled workers; and group 5 was unskilled workers. For study participants who indicated they were married at the time of the index date, SES was designated as the highest level of the participant or spouse. Area of residence was classified as Copenhagen (capital), Copenhagen suburbs, Aarhus/Odense, provincial towns, rural areas and Greenland. Marital status (married, unmarried, divorced and widowed) was at the time of the designated index date.

This study was approved by the Danish Data Protection Agency. Because this study was a secondary analysis, it was determined to be exempt from full review by the Harvard TH Chan School of Public Health Institutional Review Board.

\section{RESULTS}

Demographic data for 1826 ALS cases and 182600 controls who were 25 years of age or less in 1964 were obtained from 1982 to 2013 (table 1). The largest portion of ALS cases was diagnosed between the ages of 55 years and 64 years. Overall, there was not much difference in covariates by case status. Regarding SES, the smallest percentage of study participants came from families where the highest earner worked in academia or management for both ALS cases (11.66\%) and controls (10.91\%). Very few ALS cases and controls resided in Greenland $(0.44 \%$ and $0.33 \%$, respectively). Additionally, the majority of study participants, including 1206 (66.05\%) cases and 120649 (66.07\%) 


\begin{tabular}{|c|c|c|c|c|}
\hline \multirow[b]{2}{*}{ Characteristics } & \multicolumn{2}{|c|}{$\begin{array}{l}\text { Controls } \\
(n=182600)\end{array}$} & \multicolumn{2}{|c|}{$\begin{array}{l}\text { Cases } \\
(\mathrm{n}=1826)\end{array}$} \\
\hline & $\mathrm{n}$ & $\%$ & $\mathrm{n}$ & $\%$ \\
\hline Male sex & 107900 & 59.09 & 1079 & 59.09 \\
\hline \multicolumn{5}{|l|}{ Age (years) } \\
\hline$<45$ & 26100 & 14.29 & 261 & 14.29 \\
\hline $45-54$ & 45700 & 25.03 & 457 & 25.03 \\
\hline $55-64$ & 71100 & 38.94 & 711 & 38.94 \\
\hline $65-74$ & 39700 & 21.74 & 397 & 21.74 \\
\hline \multicolumn{5}{|l|}{ Socioeconomic status* } \\
\hline Academics and managers & 19916 & 10.91 & 213 & 11.66 \\
\hline High salary positions & 25302 & 13.86 & 251 & 13.75 \\
\hline Low salary positions & 32480 & 17.79 & 336 & 18.40 \\
\hline Skilled workers & 54929 & 30.08 & 522 & 28.59 \\
\hline Unskilled workers & 28294 & 15.50 & 281 & 15.39 \\
\hline Unknown & 21679 & 11.87 & 223 & 12.21 \\
\hline \multicolumn{5}{|c|}{ Residence at diagnosis/index date } \\
\hline Copenhagen & 18693 & 10.24 & 199 & 10.90 \\
\hline Copenhagen suburbs & 42762 & 23.42 & 414 & 22.67 \\
\hline Aarhus/Odense & 18026 & 9.87 & 167 & 9.15 \\
\hline Provincial towns & 74182 & 40.63 & 779 & 42.66 \\
\hline Rural areas & 27443 & 15.03 & 249 & 13.64 \\
\hline Greenland & 594 & 0.33 & 8 & 0.44 \\
\hline Unknown & 900 & 0.49 & 10 & 0.55 \\
\hline \multicolumn{5}{|l|}{ Marital status } \\
\hline Married & 120649 & 66.07 & 1206 & 66.05 \\
\hline Unmarried & 27308 & 14.96 & 267 & 14.62 \\
\hline Divorced & 25683 & 14.07 & 266 & 14.57 \\
\hline Widowed & 8959 & 4.76 & 87 & 4.91 \\
\hline Unknown & 1 & 0.00 & 0 & 0.00 \\
\hline
\end{tabular}

*Where a spouse's job title was available, socioeconomic status is based on the highest status of the study participant or his/her spouse.

controls, were identified as married at the time of their index date.

Among men, there was a modest 15\% increased odds of ALS in those who worked in agriculture, hunting, forestry or fishing in the crude analysis that increased to a significant $21 \%$ increase after adjusting for SES, location and marital status (adjusted OR $(\mathrm{aOR})=1.21 ; 95 \%$ CI 1.02 to $1.45 ; \mathrm{p}=0.03$ ) (table 2). We also observed a notable, yet not statistically significant, increase in a very small sample of four men employed in tobacco processing and packaging $(\mathrm{aOR}=2.58$; 95\% CI 0.95 to 7.00 ). Additionally, there was a positive association for those employed in construction, which became significant after adjustment for confounders $(\mathrm{aOR}=1.21 ; 95 \% \mathrm{CI} 1.05$ to $1.39 ; \mathrm{p}=0.01)$. Most construction subcategories had elevated ORs, but only general contracting was significantly elevated $(\mathrm{aOR}=1.18 ; 95 \% \mathrm{CI} 1.01$ to $1.38 ; \mathrm{p}=0.04)$. Additionally, there was decreased odds of ALS in men employed in health and research that was significant in the crude analysis, but was no longer significant in the multivariable analysis $(\mathrm{aOR}=0.86$; $95 \%$ CI 0.71 to 1.02 ).

Results for the investigation of occupations associated with an ALS diagnosis in women revealed significance only for certain occupations with reduced odds of ALS (table 3). Specifically, women employed in residential and commercial cleaning services had 30\% reduced odds of being diagnosed with ALS compared with those who were never employed in such industries in crude analysis, which maintained significance after adjustment for SES, location and marital status $(\mathrm{aOR}=0.69 ; 95 \% \mathrm{CI} 0.52$ to $0.93 ; p=0.04)$. Additionally, similar to the results seen in men, there was a seemingly protective association with employment of women in health and research that was no longer statistically significant in adjusted analyses ( $\mathrm{aOR}=0.90 ; 95 \% \mathrm{CI} 0.52$, to 1.06 ).

Table 4 shows the results of our evaluation of timing of employment in occupations with statistically significant elevated risk of ALS, specifically for men who were ever employed in the agriculture, hunting, forestry, or fishing industry and those in the construction industry. For agriculture, hunting, forestry and fishing, there were no obvious trends by any of the timing variables. Associations for occupations held any time preceding $(p=0.04)$, at least 5 years prior $(p<0.05)$, and at least 10 years prior $(\mathrm{p}=0.04)$ to the index date were fairly consistent with a $20 \%-21 \%$ increase in odds. However, there was a steady increase in ALS for men in construction with increasing lag periods with $21 \%$ increase for employment any time prior to the index date $(\mathrm{p}=0.01), 23 \%$ increase for jobs at least 5 years prior $(p=0.02)$ and $25 \%$ for employment at least 10 years prior $(\mathrm{p}=0.01)$ to the index date. Additionally, employment in agriculture, hunting, forestry or fishing for less than 1 year was associated with elevated OR of 1.28 (95\% CI 1.04 to $1.58 ; \mathrm{p}<0.05)$. Similar results were seen for men who worked in construction for less than 1 year $(\mathrm{aOR}=1.25 ; 95 \% \mathrm{CI} 1.06$ to $1.47 ; \mathrm{p}=0.02)$. Furthermore, those who were first employed in construction between the age of 21 years and 30 years had higher odds of ALS $(\mathrm{aOR}=1.22 ; 95 \% \mathrm{CI} 1.03$ to $1.45 ; \mathrm{p}<0.05)$ and those employed between 1965 and 1974 also had higher odds compared with those never employed in construction $(\mathrm{aOR}=1.35$; 95\% CI 1.13 to $1.61 ; \mathrm{p}=0.03)$. There were no significant timing factors for women employed in cleaning services.

\section{DISCUSSION}

Our analysis revealed a significant positive association between employment in the agriculture, hunting, forestry or fishing industries, as well as increased odds in men involved in construction projects. As expected, results were not consistent for occupational categories between men and women. Among women, there was a seemingly protective association in those who worked in cleaning services. However, it is important to note that results for women were largely based on particularly small numbers of people in the different occupational categories; $16 \%$ of the women in our study had never entered the workforce.

Several prior studies found a positive association between agricultural occupations and ALS, which are consistent with our combined agriculture, hunting, forestry and fishing occupation category. ${ }^{7}$ However, a recent study in Sweden showed no association of agricultural, forestry and fishing work in an age-adjusted and sex-adjusted analysis. ${ }^{18}$ As we thought sex could possibly be an effect modifier of occupation, we stratified our analysis to better assess expected differences in occupational associations between men and women, and saw a positive association in men, but not in women. This same difference was observed in a stratified analysis from a different earlier investigation in Sweden. ${ }^{19}$ We also saw increased odds of ALS in men employed for less than 1 year in agriculture, hunting, forestry or fishing, while those with 1-4 years of experience had higher odds that were only marginally significant. These results might reflect exposures to pesticides and physical exertion experienced by seasonal labourers tasked with harvesting crops, while those with more than 4 years of experience may be in managerial 
Table 2 Association between occupations and amyotrophic lateral sclerosis case status in men using conditional logistical regression

\begin{tabular}{|c|c|c|c|c|c|c|}
\hline \multirow[b]{2}{*}{ Occupations } & \multirow{2}{*}{$\begin{array}{l}\text { Cases with job } \\
\mathrm{n}=1079 \\
\mathrm{n}(\%)\end{array}$} & \multirow{2}{*}{$\begin{array}{l}\text { Controls with job } \\
n=107900 \\
n(\%)\end{array}$} & \multicolumn{2}{|c|}{ Crude } & \multicolumn{2}{|c|}{ Adjusted* } \\
\hline & & & OR & $95 \% \mathrm{Cl}$ & OR & $95 \% \mathrm{Cl}$ \\
\hline Agriculture and farming & $154(14.27)$ & $13541(12.55)$ & 1.16 & 0.98 to 1.38 & 1.20 & 0.99 to 1.44 \\
\hline Forestry & $16(1.48)$ & $1373(1.27)$ & 1.17 & 0.71 to 1.92 & 1.25 & 0.75 to 2.09 \\
\hline Hunting and fishing & $20(1.85)$ & $1987(1.84)$ & 1.01 & 0.65 to 1.57 & 1.04 & 0.65 to 1.64 \\
\hline Meat products & $78(7.23)$ & $6809(6.31)$ & 1.16 & 0.92 to 1.46 & 1.09 & 0.85 to 1.41 \\
\hline Dairy products & $39(3.61)$ & 4094 (3.79) & 0.95 & 0.69 to 1.31 & 1.00 & 0.72 to 1.40 \\
\hline Preserved food products & $57(5.28)$ & $4659(4.32)$ & 1.24 & 0.95 to 1.62 & 1.28 & 0.97 to 1.70 \\
\hline Grain and sugar products & $60(5.56)$ & $5940(5.51)$ & 1.01 & 0.78 to 1.31 & 1.05 & 0.80 to 1.39 \\
\hline Beverages & $42(3.89)$ & $3982(3.69)$ & 1.06 & 0.78 to 1.44 & 1.06 & 0.76 to 1.46 \\
\hline Paper and printing industry & $104(9.64)$ & $9878(9.15)$ & 1.06 & 0.86 to 1.30 & 1.08 & 0.87 to 1.34 \\
\hline Chemical production industry & $130(12.05)$ & $13206(12.24)$ & 0.98 & 0.82 to 1.18 & 1.04 & 0.85 to 1.26 \\
\hline Raw chemicals & $11(1.02)$ & $1404(1.30)$ & 0.78 & 0.43 to 1.42 & 0.85 & 0.47 to 1.55 \\
\hline Medical goods and personal care items & $24(2.22)$ & $2640(2.45)$ & 0.91 & 0.60 to 1.36 & 0.90 & 0.59 to 1.38 \\
\hline Petroleum products & $97(8.99)$ & $9321(8.64)$ & 1.05 & 0.85 to 1.29 & 1.12 & 0.90 to 1.39 \\
\hline Other chemical industry & $89(8.25)$ & $9020(8.36)$ & 0.99 & 0.79 to 1.23 & 1.07 & 0.85 to 1.34 \\
\hline Stones products industry & $90(8.34)$ & $9395(8.71)$ & 0.95 & 0.77 to 1.19 & 0.99 & 0.79 to 1.24 \\
\hline Metal products industry & $326(30.21)$ & $31524(29.22)$ & 1.05 & 0.92 to 1.20 & 1.06 & 0.92 to 1.22 \\
\hline Metal foundry & $35(3.24)$ & $3483(3.23)$ & 1.01 & 0.72 to 1.41 & 0.94 & 0.65 to 1.36 \\
\hline Metal goods and pipe factory & $188(17.42)$ & $18001(16.68)$ & 1.05 & 0.90 to 1.24 & 1.09 & 0.92 to 1.30 \\
\hline Drainage, sewer, plumbing & $63(5.84)$ & $5856(5.43)$ & 1.08 & 0.84 to 1.40 & 1.23 & 0.94 to 1.60 \\
\hline Paving, bricklaying & $85(7.88)$ & $8506(7.88)$ & 1.00 & 0.80 to 1.25 & 1.10 & 0.87 to 1.38 \\
\hline Carpentry & $100(9.27)$ & $8686(8.05)$ & 1.17 & 0.95 to 1.44 & 1.21 & 0.97 to 1.51 \\
\hline Electrician & $37(3.43)$ & $4793(4.44)$ & 0.76 & 0.55 to 1.06 & 0.78 & 0.54 to 1.11 \\
\hline Painting, glazing & $36(3.34)$ & $3134(2.90)$ & 1.15 & 0.83 to 1.61 & 1.24 & 0.87 to 1.77 \\
\hline Floors, insulation, roofing & $29(2.69)$ & $2461(2.28)$ & 1.18 & 0.82 to 1.72 & 1.20 & 0.80 to 1.79 \\
\hline Trade & $489(45.32)$ & $50796(47.08)$ & 0.93 & 0.83 to 1.05 & 0.95 & 0.87 to 1.14 \\
\hline Wholesale & $365(33.83)$ & $37285(34.56)$ & 0.97 & 0.85 to 1.10 & 0.99 & 0.87 to 1.14 \\
\hline Retail & $255(23.63)$ & $26245(24.32)$ & 0.96 & 0.84 to 1.11 & 0.96 & 0.82 to 1.12 \\
\hline Restaurant/hotel & $103(9.55)$ & 10855 (10.06) & 0.94 & 0.76 to 1.16 & 0.93 & 0.74 to 1.17 \\
\hline Transportation & $270(25.02)$ & 26691 (24.74) & 1.02 & 0.89 to 1.17 & 1.05 & 0.91 to 1.22 \\
\hline Ground (taxi, bus, carrier, train) & $188(17.42)$ & $18537(17.18)$ & 1.02 & 0.87 to 1.19 & 1.03 & 0.87 to 1.22 \\
\hline Water & $78(7.23)$ & $6678(6.19)$ & 1.18 & 0.94 to 1.49 & 1.18 & 0.93 to 1.51 \\
\hline Air & $17(1.58)$ & $2094(1.94)$ & 0.81 & 0.50 to 1.31 & 0.89 & 0.55 to 1.44 \\
\hline Operations and support & $48(4.45)$ & $4751(4.40)$ & 1.01 & 0.76 to 1.35 & 1.12 & 0.83 to 1.51 \\
\hline Postal, telephone, telegraph service & $94(8.71)$ & $8028(7.44)$ & 1.19 & 0.96 to 1.47 & 1.16 & 0.92 to 1.46 \\
\hline Banking, insurance, finance & $115(10.66)$ & $12182(11.29)$ & 0.94 & 0.77 to 1.14 & 0.91 & 0.74 to 1.12 \\
\hline Property management & $58(5.38)$ & $5531(5.13)$ & 1.07 & 0.83 to 1.39 & 1.15 & 0.88 to 1.50 \\
\hline Professional (legal, financial, engineer) & $189(17.52)$ & $19204(17.80)$ & 0.98 & 0.84 to 1.15 & 0.95 & 0.80 to 1.13 \\
\hline Lab technician & $18(1.67)$ & $1807(1.67)$ & 1.00 & 0.62 to 1.59 & 0.83 & 0.49 to 1.42 \\
\hline Equipment rental & $40(3.71)$ & $3680(3.41)$ & 1.09 & 0.79 to 1.50 & 1.07 & 0.76 to 1.50 \\
\hline
\end{tabular}


Table 2 continued

\begin{tabular}{|c|c|c|c|c|c|c|}
\hline \multirow[b]{2}{*}{ Occupations } & \multirow{2}{*}{$\begin{array}{l}\text { Cases with job } \\
\mathrm{n}=1079 \\
\mathrm{n}(\%)\end{array}$} & \multirow{2}{*}{$\begin{array}{l}\text { Controls with job } \\
n=107900 \\
n(\%)\end{array}$} & \multicolumn{2}{|c|}{ Crude } & \multicolumn{2}{|c|}{ Adjusted* } \\
\hline & & & OR & $95 \% \mathrm{Cl}$ & OR & $95 \% \mathrm{Cl}$ \\
\hline Police, guard, security & $14(1.30)$ & $1952(1.81)$ & 0.71 & 0.42 to 1.21 & 0.71 & 0.41 to 1.23 \\
\hline Military, defencet & $102(9.45)$ & $8833(8.19)$ & 1.17 & 0.95 to 1.44 & 1.15 & 0.92 to 1.43 \\
\hline Water delivery/sewage removal & $14(1.30)$ & $1680(1.56)$ & 0.83 & 0.49 to 1.41 & 0.87 & 0.50 to 1.50 \\
\hline Electricity plant & $18(1.67)$ & $2256(2.09)$ & 0.79 & 0.50 to 1.27 & 0.81 & 0.50 to 1.32 \\
\hline Heat/gas company & $10(0.93)$ & $631(0.58)$ & 1.59 & 0.85 to 2.98 & 1.44 & 0.71 to 2.91 \\
\hline Cleaning services & $48(4.45)$ & $5381(4.99)$ & 0.89 & 0.66 to 1.19 & 0.93 & 0.67 to 1.28 \\
\hline Health and research & $219(20.30)$ & $24864(23.04)$ & 0.85 & 0.73 to 0.98 & 0.86 & 0.73 to 1.02 \\
\hline Welfare organisations and day cares & $69(6.39)$ & $7377(6.84)$ & 0.93 & 0.73 to 1.19 & 0.78 & 0.59 to 1.03 \\
\hline Education & $91(8.43)$ & $10872(10.08)$ & 0.82 & 0.66 to 1.02 & 0.80 & 0.63 to 1.01 \\
\hline Societies, institutions, organisations & $73(6.77)$ & $7353(6.81)$ & 0.99 & 0.78 to 1.26 & 1.02 & 0.80 to 1.31 \\
\hline Entertainment & $55(5.10)$ & $5641(5.23)$ & 0.97 & 0.74 to 1.28 & 0.94 & 0.70 to 1.27 \\
\hline Repair and service & $49(4.54)$ & $4740(4.39)$ & 1.04 & 0.78 to 1.38 & 1.09 & 0.80 to 1.48 \\
\hline Laundries and dry cleaners & $22(2.04)$ & $1855(1.72)$ & 1.19 & 0.78 to 1.82 & 1.15 & 0.73 to 1.82 \\
\hline Personal services & $22(2.04)$ & $1652(1.53)$ & 1.34 & 0.88 to 2.05 & 1.34 & 0.85 to 2.13 \\
\hline
\end{tabular}

*Adjusted for socioeconomic status, residential location and marital status.

tMilitary defence includes only those with at least 1 year of service.

positions. This assertion would be consistent with results from Sweden showing increased odds of ALS in men who were farm workers but no significant increase in men identified as farm and forestry managers. ${ }^{19}$

Our findings of increased ALS in men ever employed in construction are consistent with results from a study in Massachusetts which indicated significantly higher odds of ALS, after adjusting for sex, age and residential area, for those employed in construction, ${ }^{20}$ and another study in New England that found elevated occupational risk for ALS in construction workers. ${ }^{21}$ However, our results are contrary to those from a Swedish population which reported no association with ALS and construction based on census data ascertained during three time points (1970, 1980 and 1990), ${ }^{18}$ and to the results of a study in the USA that reported no significant association between construction work and ALS mortality, ${ }^{22}$ although the latter study only considered self-reported longest-held occupation. However, some of these differences could result from different distributions of specific jobs at time periods within the larger categories in the different populations.

When examining timing factors of employment, we also saw higher odds of ALS in construction workers who started work between 1965 and 1974. A large portion of construction workers identified as general contractors (approximately 60\%) and 98\% of construction workers who identified multiple construction titles also identified as general contractors. Thus, most of the constructions workers in this population performed several different tasks and were probably exposed to a large variety of environmental toxicants and potential mutagens including asbestos, metal dust, mineral dust, asphalt, diesel exhaust and organic solvents.

Neurotoxicants commonly associated with agriculture, hunting, forestry and fishing as well as construction work are lead and diesel exhaust. Although Denmark banned interior lead-based paint several decades ago, construction workers involved in home renovations can still be exposed to lead via paint dust. ${ }^{23}$ In addition, use of lead ammunition and consumption of game meat in hunters, ${ }^{24}$ continued use of leaded fishing weights and tackle by fishermen, despite a ban on the import and sale of such equipment in $2002,{ }^{24}$ and agricultural use of sludge, which causes lead to accumulate in topsoil, ${ }^{25}$ increases the risk of repeated and elevated exposures to lead to workers in these industries. Lead is a well-known neurotoxicant, and previous studies have related occupational exposures to later cognitive impairments in adults. ${ }^{26}$ Additionally, through use of heavy machinery and engines used in farming, shipyards and construction, diesel exhaust is another established exposure in these industries. ${ }^{27}$ As diesel exhaust is composed of several toxic compounds, ${ }^{27}$ such as aresenic, benzene, andformaldehyde, the ability of diesel exhaust exposure to impact oxidative stress and neuroinflammation has increased concern that it may lead to neurodegeneration. ${ }^{28} 29$ However, with the well-established neurotoxicity of pesticides, ${ }^{30} 31$ these exposures in subjects who worked in agriculture and forestry could be responsible for our study observations in this group.

The notably positive results seen for men employed in the tobacco industry are interesting, particularly because workers in the tobacco industry have been provided free tobacco products, primarily cigarettes, during earlier production years, which likely meant a high smoking prevalence among these employees. Thus, Danish tobacco workers have significantly increased risk of lung cancer-a well-known health outcome of tobacco smoking-of 1.76 in men and 2.30 in women. ${ }^{32}$ Studies generally suggest smoking as a potential risk factor for ALS. ${ }^{33} 34$ Our results could be consistent with an association driven by smoking, although the association among tobacco workers in our study was much larger than associations seen with smoking in previous studies. ${ }^{34} 35$

Given findings relating physical trauma to ALS, ${ }^{36}$ it is important to note the high risk of physical injury and musculoskeletal disorders due to overexertion and repetitive motion in the occupations shown to have significantly positive results in our analysis. ${ }^{3738}$ Physical activity has been proposed to be related to the development of ALS, possibly through increases in tissue metabolism, which may increase oxidative stress or potency of neurotoxins, leading to neurodegeneration. ${ }^{39}$ Though some studies have reported no significant associations with physical activity and ALS, ${ }^{40}$ several epidemiological studies have noted a link between ALS and physical activity. ${ }^{40}$ Specifically, many have observed an increase in ALS associated with occupational strain. ${ }^{9}$ 
Table 3 Association between occupations and amyotrophic lateral sclerosis case status in women using conditional logistical regression

\begin{tabular}{|c|c|c|c|c|c|c|}
\hline \multirow[b]{2}{*}{ Occupations } & \multirow{2}{*}{$\begin{array}{l}\text { Cases with job } \\
\mathrm{n}=747 \\
\mathrm{~N}(\%)\end{array}$} & \multirow{2}{*}{$\begin{array}{l}\text { Controls with job } \\
\mathrm{n}=74700\end{array}$} & \multicolumn{2}{|c|}{ Crude } & \multicolumn{2}{|c|}{ Adjusted* } \\
\hline & & & OR & $95 \% \mathrm{Cl}$ & OR & $95 \% \mathrm{Cl}$ \\
\hline Agriculture, hunting, forestry, fishing & $59(7.90)$ & $5145(6.89)$ & 1.16 & 0.89 to 1.52 & 1.15 & 0.86 to 1.53 \\
\hline Agriculture and farming & $51(6.83)$ & $4706(6.30)$ & 1.09 & 0.82 to 1.45 & 1.11 & 0.82 to 1.51 \\
\hline Forestry & $5(0.67)$ & $378(0.51)$ & 1.33 & 0.55 to 3.21 & 1.40 & 0.58 to 3.40 \\
\hline Hunting and fishing & $3(0.40)$ & $145(0.19)$ & 2.07 & 0.66 to 6.53 & 0.75 & 0.10 to 5.35 \\
\hline Meat products & $28(3.75)$ & $3161(4.23)$ & 0.88 & 0.60 to 1.29 & 0.92 & 0.62 to 1.36 \\
\hline Dairy products & $19(2.54)$ & $2012(2.69)$ & 0.94 & 0.60 to 1.49 & 0.91 & 0.56 to 1.47 \\
\hline Preserved food products & $42(5.62)$ & $3145(4.21)$ & 1.36 & 0.99 to 1.86 & 1.33 & 0.95 to 1.87 \\
\hline Grain and sugar products & $58(7.76)$ & $6357(8.51)$ & 0.91 & 0.69 to 1.19 & 0.92 & 0.69 to 1.23 \\
\hline Beverages & $14(1.87)$ & $1576(2.11)$ & 0.89 & 0.52 to 1.51 & 1.00 & 0.58 to 1.70 \\
\hline Paper and printing industry & $56(7.50)$ & $5670(7.59)$ & 0.99 & 0.75 to 1.30 & 0.98 & 0.73 to 1.31 \\
\hline Chemical Industry & $70(9.37)$ & $7067(9.46)$ & 0.99 & 0.77 to 1.27 & 0.93 & 0.71 to 1.22 \\
\hline Raw chemicals & $7(0.94)$ & $527(0.71)$ & 1.33 & 0.63 to 2.82 & 1.25 & 0.55 to 2.80 \\
\hline Medical goods and personal care items & $25(3.35)$ & $2994(4.01)$ & 0.83 & 0.56 to 1.24 & 0.81 & 0.52 to 1.24 \\
\hline Petroleum products & $42(5.62)$ & $3891(5.21)$ & 1.08 & 0.79 to 1.48 & 0.99 & 0.70 to 1.40 \\
\hline Other chemical industry & $42(5.62)$ & $4158(5.57)$ & 0.99 & 0.79 to 1.23 & 0.99 & 0.71 to 1.38 \\
\hline Stones products industry & $20(2.68)$ & $1908(2.55)$ & 1.05 & 0.67 to 1.64 & 1.18 & 0.75 to 1.84 \\
\hline Metal products industry & $81(10.84)$ & $8744(11.71)$ & 0.92 & 0.73 to 1.16 & 0.91 & 0.71 to 1.16 \\
\hline Metal foundry & $3(0.40)$ & $717(0.96)$ & 0.42 & 0.13 to 1.30 & 0.45 & 0.15 to 1.41 \\
\hline Metal goods and pipe factory & $48(6.43)$ & $4926(6.59)$ & 0.97 & 0.73 to 1.31 & 0.97 & 0.71 to 1.32 \\
\hline Drainage, sewer, plumbing & $6(0.80)$ & $523(0.70)$ & 1.15 & 0.51 to 2.58 & 1.26 & 0.56 to 2.83 \\
\hline Paving, bricklaying & $5(0.67)$ & $413(0.55)$ & 1.21 & 0.50 to 2.94 & 1.25 & 0.52 to 3.04 \\
\hline Carpentry & $5(0.67)$ & $635(0.85)$ & 0.79 & 0.33 to 1.90 & 0.85 & 0.35 to 2.05 \\
\hline Electrician & $9(1.20)$ & $804(1.08)$ & 1.12 & 0.58 to 2.17 & 1.07 & 0.53 to 2.17 \\
\hline Painting, glazing & $4(0.54)$ & $497(0.67)$ & 0.80 & 0.30 to 2.16 & 0.91 & 0.34 to 2.45 \\
\hline Floors, insulation, roofing & $2(0.27)$ & $247(0.33)$ & 0.81 & 0.20 to 3.26 & 0.96 & 0.24 to 3.88 \\
\hline Trade & $307(41.10)$ & $31558(42.25)$ & 0.95 & 0.82 to 1.11 & 0.95 & 0.81 to 1.12 \\
\hline Wholesale & $164(21.95)$ & $15718(21.04)$ & 1.06 & 0.89 to 1.26 & 1.06 & 0.88 to 1.27 \\
\hline Retail & $207(27.71)$ & $22425(30.02)$ & 0.89 & 0.76 to 1.05 & 0.89 & 0.75 to 1.06 \\
\hline Restaurant/hotel & $120(16.06)$ & $13199(17.67)$ & 0.89 & 0.73 to 1.09 & 0.91 & 0.74 to 1.13 \\
\hline Transportation & $64(8.57)$ & $7400(9.91)$ & 0.85 & 0.66 to 1.10 & 0.88 & 0.67 to 1.16 \\
\hline Ground (taxi, bus, carrier, train) & $32(4.28)$ & $3647(4.88)$ & 0.87 & 0.61 to 1.25 & 0.89 & 0.61 to 1.29 \\
\hline Water & $15(2.01)$ & $1784(2.39)$ & 0.84 & 0.50 to 1.40 & 0.91 & 0.54 to 1.53 \\
\hline Air & $8(1.07)$ & $969(1.30)$ & 0.82 & 0.41 to 1.66 & 0.81 & 0.38 to 1.71 \\
\hline Operations and support & $21(2.81)$ & $1883(2.52)$ & 1.12 & 0.72 to 1.73 & 1.09 & 0.68 to 1.75 \\
\hline Postal, telephone, telegraph service & $50(6.69)$ & $4463(5.97)$ & 1.13 & 0.85 to 1.51 & 1.18 & 0.87 to 1.59 \\
\hline Banking, insurance, finance & $106(14.19)$ & $11455(15.33)$ & 0.91 & 0.74 to 1.12 & 0.96 & 0.77 to 1.19 \\
\hline Property management & $26(3.48)$ & $2651(3.55)$ & 1.22 & 0.92 to 1.61 & 1.21 & 0.90 to 1.63 \\
\hline Professional (legal, financial, engineer) & $114(15.26)$ & $12455(16.67)$ & 0.90 & 0.74 to 1.10 & 0.92 & 0.74 to 1.14 \\
\hline Lab technician & $8(1.07)$ & $822(1.10)$ & 0.97 & 0.48 to 1.96 & 0.98 & 0.46 to 2.07 \\
\hline Equipment rental & $13(1.74)$ & $1230(1.65)$ & 1.06 & 0.61 to 1.84 & 1.04 & 0.59 to 1.85 \\
\hline Public administration & 485 (64.93) & $50648(67.80)$ & 0.88 & 0.75 to 1.02 & 0.96 & 0.81 to 1.13 \\
\hline
\end{tabular}


Table 3 continued

\begin{tabular}{|c|c|c|c|c|c|c|}
\hline \multirow[b]{2}{*}{ Occupations } & \multirow{2}{*}{$\begin{array}{l}\text { Cases with job } \\
\mathrm{n}=747 \\
\mathrm{~N}(\%)\end{array}$} & \multirow{2}{*}{$\begin{array}{l}\text { Controls with job } \\
n=74700 \\
N(\%)\end{array}$} & \multicolumn{2}{|c|}{ Crude } & \multicolumn{2}{|c|}{ Adjusted* } \\
\hline & & & OR & $95 \% \mathrm{Cl}$ & OR & $95 \% \mathrm{Cl}$ \\
\hline Police, guard, security & $12(1.61)$ & $1121(1.50)$ & 1.07 & 0.60 to 1.90 & 1.14 & 0.64 to 2.03 \\
\hline Military, defencet & $10(1.34)$ & $782(1.05)$ & 1.28 & 0.68 to 2.40 & 1.11 & 0.55 to 2.25 \\
\hline Electricity plant & $2(0.27)$ & $499(0.67)$ & 0.40 & 0.10 to 1.60 & 0.43 & 0.11 to 1.73 \\
\hline Heat/gas company & $2(0.27)$ & $193(0.26)$ & 1.04 & 0.26 to 4.18 & 1.15 & 0.28 to 4.64 \\
\hline Cleaning services & $60(8.03)$ & $8231(11.02)$ & 0.70 & 0.54 to 0.92 & 0.69 & 0.52 to 0.93 \\
\hline Health and research & $296(39.63)$ & $32351(43.31)$ & 0.85 & 0.74 to 0.99 & 0.90 & 0.77 to 1.06 \\
\hline Welfare organisations and day cares & $161(21.55)$ & $16764(22.44)$ & 0.95 & 0.80 to 1.13 & 1.01 & 0.84 to 1.22 \\
\hline Education & $95(12.72)$ & $9687(12.97)$ & 0.98 & 0.79 to 1.22 & 0.94 & 0.74 to 1.19 \\
\hline Societies, institutions, organisations & $63(8.43)$ & $6436(8.62)$ & 0.98 & 0.75 to 1.27 & 1.03 & 0.79 to 1.34 \\
\hline Entertainment & $27(3.61)$ & $3289(4.40)$ & 0.81 & 0.55 to 1.20 & 0.87 & 0.57 to 1.31 \\
\hline Repair and service & $5(0.67)$ & $559(0.75)$ & 0.89 & 0.37 to 2.16 & 0.99 & 0.41 to 2.40 \\
\hline Laundries and dry cleaners & $21(2.81)$ & $2820(3.78)$ & 0.74 & 0.48 to 1.14 & 0.79 & 0.51 to 1.24 \\
\hline Personal services & $15(2.01)$ & $1958(2.62)$ & 0.76 & 0.46 to 1.27 & 0.75 & 0.43 to 1.31 \\
\hline
\end{tabular}

${ }^{*}$ Adjusted for socioeconomic status, residential location and marital status.

†Military defence includes only those with at least 1 year of service.

There was also an apparent protective association for women employed in cleaning services as well as in crude analyses for men and women ever employed in health and research fields. Both of these occupations are consistently exposed to disinfectants and are familiar with protocols for properly cleaning surfaces to prevent contamination and infection. A recent study in Italy found a higher risk of ALS in people employed in occupations with constant contact with the public, and subsequently at higher risk of contracting infection, such as bank tellers, general practitioners and sales representatives. ${ }^{41}$ Although we did not see similar associations in our population, the potentially

Table 4 Associations between timing of occupation and amyotrophic lateral sclerosis diagnosis in men

\begin{tabular}{|c|c|c|c|c|c|c|}
\hline & \multicolumn{3}{|c|}{ Agriculture, hunting, forestry, fishing } & \multicolumn{3}{|l|}{ Construction } \\
\hline & $\begin{array}{l}\text { Cases } \\
\text { n (\%) }\end{array}$ & $\begin{array}{l}\text { Controls } \\
\mathrm{n}(\%)\end{array}$ & OR $(95 \% \mathrm{Cl})$ & $\begin{array}{l}\text { Cases } \\
\mathrm{n}(\%)\end{array}$ & $\begin{array}{l}\text { Controls } \\
\mathrm{n}(\%)\end{array}$ & OR $(95 \% \mathrm{Cl})$ \\
\hline Longest job* & $33(3.06 \%)$ & $2800(2.59 \%)$ & 1.14 (0.80 to 1.63$)$ & $69(6.39 \%)$ & $5945(5.51 \%)$ & $1.17(0.92$ to 1.51$)$ \\
\hline \multicolumn{7}{|l|}{$\begin{array}{l}\text { Years before } \\
\text { diagnosist‡ }\end{array}$} \\
\hline 0 years before & $181(16.77 \%)$ & $16072(14.90 \%)$ & 1.21 (1.01 to 1.44$)$ & $396(36.70 \%)$ & $37256(34.53 \%)$ & $1.21(1.05$ to 1.38$)$ \\
\hline 5 years before & $175(16.22 \%)$ & $15539(14.40 \%)$ & $1.20(1.01$ to 1.44$)$ & $389(36.05 \%)$ & $36121(33.48 \%)$ & $1.23(1.07$ to 1.41$)$ \\
\hline 10 years before & $170(15.76 \%)$ & $14826(13.74 \%)$ & 1.21 (1.01 to 1.45$)$ & $375(34.75 \%)$ & $34454(31.93 \%)$ & 1.25 (1.09 to 1.44$)$ \\
\hline \multicolumn{7}{|c|}{$\begin{array}{l}\text { Number of years in the } \\
\text { job } \neq\end{array}$} \\
\hline None & $901(83.50 \%)$ & $92127(85.38 \%)$ & Reference & $687(63.67 \%)$ & $71278(66.06 \%)$ & Reference \\
\hline$<1$ year & $120(11.12 \%)$ & $9964(9.23 \%)$ & $1.28(1.04$ to 1.58$)$ & $230(21.32 \%)$ & $20363(18.87 \%)$ & 1.25 (1.06 to 1.47$)$ \\
\hline $1-4$ years & $45(4.17 \%)$ & $3676(3.41 \%)$ & 1.36 (0.99 to 1.87$)$ & $93(8.62 \%)$ & $9053(8.39 \%)$ & $1.18(0.94$ to 1.49$)$ \\
\hline$\geq 5$ years & $13(1.20 \%)$ & $2133(1.98 \%)$ & 0.64 (0.36 to 1.14$)$ & $69(6.39 \%)$ & $7206(6.68 \%)$ & 1.13 (0.87 to 1.46$)$ \\
\hline \multicolumn{7}{|l|}{$\begin{array}{l}\text { Age at first } \\
\text { employment‡ }\end{array}$} \\
\hline None & $901(83.50 \%)$ & $92127(85.38 \%)$ & Reference & $687(63.67 \%)$ & $71278(66.06 \%)$ & Reference \\
\hline$\leq 20$ years & $51(4.73 \%)$ & 4609 (4.27\%) & 1.18 (0.85 to 1.64$)$ & $63(5.84 \%)$ & $5988(5.55 \%)$ & 1.27 (0.95 to 1.68$)$ \\
\hline $21-30$ years & $84(7.78 \%)$ & $7453(6.91 \%)$ & 1.22 (0.96 to 1.54$)$ & $218(20.20 \%)$ & $20402(18.91 \%)$ & $1.22(1.03$ to 1.45$)$ \\
\hline $31-40$ years & $25(2.32 \%)$ & $2138(1.98 \%)$ & 1.24 (0.81 to 1.89$)$ & $65(6.02 \%)$ & $6110(5.66 \%)$ & 1.12 (0.85 to 1.48$)$ \\
\hline$\geq 41$ years & $18(1.67 \%)$ & $1573(1.46 \%)$ & $1.23(0.75$ to 2.00$)$ & $46(4.26 \%)$ & $4122(3.82 \%)$ & 1.21 (0.89 to 1.67$)$ \\
\hline \multicolumn{7}{|c|}{$\begin{array}{l}\text { Calendar year of first } \\
\text { employment‡ }\end{array}$} \\
\hline None & $901(83.50 \%)$ & $92127(85.38 \%)$ & Reference & $687(63.67 \%)$ & $71278(66.06 \%)$ & Reference \\
\hline$\leq 1964$ & $11(1.02 \%)$ & $1228(1.14 \%)$ & 0.94 (0.51 to 1.72 ) & $16(1.48 \%)$ & $1673(1.55 \%)$ & 1.07 (0.64 to 1.77$)$ \\
\hline 1965-1974 & $75(6.95 \%)$ & $6454(5.98 \%)$ & 1.23 (0.96 to 1.57$)$ & $188(17.42 \%)$ & $15479(14.35 \%)$ & 1.35 (1.13 to 1.61$)$ \\
\hline 1975-1984 & $56(5.19 \%)$ & $4544(4.21 \%)$ & 1.32 (0.98 to 1.78$)$ & $98(9.08 \%)$ & $10205(9.46 \%)$ & 1.05 (0.83 to 1.32$)$ \\
\hline$\geq 1985$ & $33(3.06 \%)$ & $3313(3.07 \%)$ & 1.13 (0.76 to 1.67$)$ & $90(8.34 \%)$ & $9265(8.59 \%)$ & 1.15 (0.90 to 1.49$)$ \\
\hline
\end{tabular}

${ }^{*}$ Models adjusted for socioeconomic status, residential location, marital status and duration.

tModels are separate for each lagged exposure. Percentages presented are for the distribution of subjects with exposure in each case or control group. ¥All models adjusted for socioeconomic status, residential location and marital status. 
reduced risk of infection in health and research fields, and in women employed in cleaning services could possibly be attributed to disease prevention practices and reduced risk of contracting various infectious diseases infections.

Our study has identified various occupations associated with ALS incidence with the added strength of a large population-based study sample and prospective assessment of all occupations held between 1964 and before ALS diagnoses occurred. Nonetheless, we do acknowledge that there are also some limitations to our study. The occupation registration data used in our analysis only goes back as far as 1964. Therefore, there may be some occupation exposure misclassification, especially regarding timing and length of employment. However, we attempted to control for this possibility by limiting our analysis to subjects 25 years of age or less at the time of the initiation of the occupation registration to minimise the chance of occupation before the start of the data. In this study, we did not evaluate individual toxicant exposures; thus, we were unable to evaluate dose-response relationships. There is also some chance of misclassification of ALS status, but prior work of ours has found quite good validity of the hospital registry data. ${ }^{11}$ We were also unable to evaluate potential confounding or effect modification by smoking status, which has been suggested as a possible risk factor for ALS. ${ }^{33}$ However, a study using data from the Cancer Prevention Study II observed no influence of adjustment for smoking in a study of occupation categories and ALS mortality. ${ }^{22}$ Additionally, data from population surveillance have suggested that the SES variable we used is correlated with smoking habits in Denmark. ${ }^{42}$ Therefore, we may have indirectly adjusted for smoking status by using our SES variable in the multivariable analyses. Furthermore, in a sensitivity analysis, chronic obstructive pulmonary disease had no significant influence as a potential confounder or effect modifier in models with statistically significant results. Additionally, the median (IQR) of occupational categories that subjects belonged to was 4 (3) for men and 5 (4) for women; thus some occupations may not be independent of each other. Lastly, due to multiple comparisons, it is possible that some of the significant results seen may be due to chance.

We found significant associations of various physically demanding occupations with high risk for several chemical exposures. Our findings highlight the importance of identifying specific environmental exposures as potential risk factors for ALS. Future studies of occupation and risk of ALS should evaluate the effects of employment in multiple industries over the lifetime, with a particular focus on gathering detailed information on physical exertion and toxicant exposures specific to certain job tasks.

Contributors MGW and JH: designed the study and directed its implementation. JH and OG: gathered data. ASD: performed data analysis and drafted the article. M-AK and MGW contributed to the analyses. AJS: reviewed and revised the analysis results. MGW, JH, AJS and MAK revised the manuscript.

Funding This work was supported by the National Institute of Environmental Health Sciences (grant R01 ES019188). ASD was supported in part by an NIH training grant (grant T32 ES007069).

Competing interests None declared.

Patient consent Not required.

Provenance and peer review Not commissioned; externally peer reviewed.

(c) Article author(s) (or their employer(s) unless otherwise stated in the text of the article) 2018. All rights reserved. No commercial use is permitted unless otherwise expressly granted.

\section{REFERENCES}

1 van Es MA, Hardiman O, Chio A, et al. Amyotrophic lateral sclerosis. Lancet 2017;390:2084-98.

2 Mitchell JD, Borasio GD. Amyotrophic lateral sclerosis. Lancet 2007:369:2031-41.

3 Sutedja NA, Fischer K, Veldink JH, et al. What we truly know about occupation as a risk factor for ALS: a critical and systematic review. Amyotroph Lateral Scler 2009;10(5-6):295-301.

4 Koeman T, Slottje P, Schouten LJ, et al. Occupational exposure and amyotrophic lateral sclerosis in a prospective cohort. Occup Environ Med 2017;74:578-85.

5 Capozzella A, Sacco C, Chighine A, et al. Work related etiology of amyotrophic lateral sclerosis (ALS): a meta-analysis. Ann Ig 2014;26:456-72.

6 Pamphlett R, Rikard-Bell A. Different occupations associated with amyotrophic lateral sclerosis: is diesel exhaust the link? PLoS One 2013;8:e80993.

7 Kang H, Cha ES, Choi GJ, et al. Amyotrophic Lateral Sclerosis and Agricultural Environments: A Systematic Review. J Korean Med Sci 2014;29:1610-7.

8 Gotkine M, Friedlander Y, Hochner H. Triathletes are over-represented in a population of patients with ALS. Amyotroph Lateral Scler Frontotemporal Degener 2014;15(78):534-6.

9 Beghi E, Logroscino G, Chiò A, et al. Amyotrophic lateral sclerosis, physical exercise, trauma and sports: results of a population-based pilot case-control study. Amyotroph Lateral Scler 2010;11:289-92.

10 Schmidt M, Schmidt SA, Sandegaard JL, et al. The Danish National Patient Registry: a review of content, data quality, and research potential. Clin Epidemiol 2015; 7:449-90.

11 Kioumourtzoglou MA, Seals RM, Himmerslev L, et al. Comparison of diagnoses of amyotrophic lateral sclerosis by use of death certificates and hospital discharge data in the Danish population. Amyotroph Lateral Scler Frontotemporal Degener 2015;16(3-4):224-9.

12 Pedersen CB, Gøtzsche H, Møller JO, et al. The Danish Civil Registration System. A cohort of eight million persons. Dan Med Bull 2006;53:441-9.

13 Hansen J, Lassen CF. The Supplementary Pension Fund Register. Scand J Public Health 2011;39(7 Suppl):99-102.

14 Nations U. International Standard Classification of all Economic Activities. New York: United Nations, 1968.

15 Denmark S. Statistics Denmark Business Group Code, DSE 77. Copenhagen, Denmark: Statistics Denmark 1989.

16 Applebaum KM, Malloy EJ, Eisen EA, truncation L. Left truncation, susceptibility, and bias in occupational cohort studies. Epidemiology 2011;22:599-606.

17 SAS Insititute Inc. 9.4 version. Cary, NC: SAS Institute Inc, 2013.

18 Peters TL, Kamel F, Lundholm C, et al. Occupational exposures and the risk of amyotrophic lateral sclerosis. Occup Environ Med 2017;74:87-92.

19 Gunnarsson LG, Lindberg G, Söderfeldt B, et al. Amyotrophic lateral sclerosis in Sweden in relation to occupation. Acta Neurol Scand 1991:83:394-8.

20 Fang F, Quinlan P, Ye W, et al. Workplace exposures and the risk of amyotrophic lateral sclerosis. Environ Health Perspect 2009;117:1387-92.

21 Andrew AS, Caller TA, Tandan R, et al. Environmental and Occupational Exposures and Amyotrophic Lateral Sclerosis in New England. Neurodegener Dis 2017;17(23):110-6.

22 Weisskopf MG, McCullough ML, Morozova N, et al. Prospective study of occupation and amyotrophic lateral sclerosis mortality. Am J Epidemiol 2005; 162:1146-52.

23 Scientific Committee on Toxicity EaTEProtection ECD-GHaC. Scienctific Committee on Toxicity, Ecotoxicity and The Environment Opinion on Lead - Danish Notification 98/595/DK. Opinion expressed at the 15th CSTEE plenary meeting. Brussels, Belgium, 2000.

24 Kanstrup N, Thomas VG, Krone 0, et al. The transition to non-lead rifle ammunition in Denmark: National obligations and policy considerations. Ambio 2016;45:621-8.

25 Nielsen E. Lead and inorganic lead compounds: Evaluation of health hazards and estimation of a quality criterion in soil. Copenhagen, Denmark: Danish Ministry of the Environment, 2013.

26 Weuve J, Korrick SA, Weisskopf MG, et al. Cumulative exposure to lead in relation to cognitive function in older women. Environ Health Perspect 2009;117:574-80.

27 IARC Working Group on the Evaluation of Carcinogenic Risks to Humans. Diesel and gasoline engine exhausts and some nitroarenes. IARC Monogr Eval Carcinog Risks Hum 2014;105:9-699.

28 D'Amico E, Factor-Litvak P, Santella RM, et al. Clinical perspective on oxidative stress in sporadic amyotrophic lateral sclerosis. Free Radic Biol Med 2013;65:509-27.

29 Levesque S, Taetzsch T, Lull ME, et al. Diesel exhaust activates and primes microglia: air pollution, neuroinflammation, and regulation of dopaminergic neurotoxicity. Environ Health Perspect 2011;119:1149-55.

30 Malek AM, Barchowsky A, Bowser R, et al. Pesticide exposure as a risk factor for amyotrophic lateral sclerosis: a meta-analysis of epidemiological studies: pesticide exposure as a risk factor for ALS. Environ Res 2012;117:112-9.

31 Kamel F, Umbach DM, Bedlack RS, et al. Pesticide exposure and amyotrophic lateral sclerosis. Neurotoxicology 2012;33:457-62. 
32 Pukkala E, Martinsen Jl, Lynge E, et al. Occupation and cancer - follow-up of 15 million people in five Nordic countries. Acta Oncol 2009;48:646-790.

33 Wang MD, Little J, Gomes J, et al. Identification of risk factors associated with onset and progression of amyotrophic lateral sclerosis using systematic review and metaanalysis. Neurotoxicology 2017;61.

34 Alonso A, Logroscino G, Hernán MA. Smoking and the risk of amyotrophic lateral sclerosis: a systematic review and meta-analysis. J Neurol Neurosurg Psychiatry 2010:81:1249-52.

35 Sutedja NA, Veldink JH, Fischer K, et al. Lifetime occupation, education, smoking, and risk of ALS. Neurology 2007;69:1508-14.

36 Seals RM, Hansen J, Gredal O, et al. Physical trauma and amyotrophic lateral sclerosis: a population-based study using danish national registries. Am J Epidemiol 2016:183:294-301.

37 Hoonakker P, van Duivenbooden C. Monitoring working conditions and health of older workers in Dutch construction industry. Am J Ind Med 2010;53:641-53.
38 Berg-Beckhoff G, Østergaard H, Jepsen JR. Prevalence and predictors of musculoskeletal pain among Danish fishermen - results from a cross-sectional survey. J Occup Med Toxicol 2016;11:51.

39 Longstreth WT, Nelson LM, Koepsell TD, et al. Hypotheses to explain the association between vigorous physical activity and amyotrophic lateral sclerosis. Med Hypotheses 1991;34:144-8.

40 Huisman MHB, Seelen M, de Jong SW, et al. Lifetime physical activity and the risk of amyotrophic lateral sclerosis. Journal of Neurology, Neurosurgery \& Psychiatry 2013;84:976-81.

41 D'Ovidio F, d'Errico A, Calvo A, et al. Occupations and amyotrophic lateral sclerosis: are jobs exposed to the general public at higher risk? Eur J Public Health 2017;27:643-7.

42 Osler M. Smoking habits in Denmark from 1953 to 1991: a comparative analysis of results from three nationwide health surveys among adult Danes in 1953-1954, 1986-1987 and 1990-1991. Int J Epidemiol 1992:21:862-71. 